\title{
Zoltán NAGY* \\ The question of water and management of water resources from the point of view of domestic environmental financial regulations**
}

\begin{abstract}
The article analyzes the financial instruments of water protection in the field of the Hungarian regulation, because in water management the economic regulation, which can be realized through the means of financial regulation, is of greater importance than official banning rules. Water protection and consumption can be influenced through regulation of environmental charges and regulation of other payment obligations. Financial instruments of passive water protection can be mentioned that protect the water base from excessive pollution. Such a tool is the soil load fee and the water load fee. The former is payable in the case of groundwater loading, while the latter is charged in case of surface water load. Means of active defense protect the use of water by charging for the water as an environmental element. Financial instruments of active defense include water resource contributions, usage fees, and a potential instrument could be water tax. The article also presents a sketchy concept of water tax as a possible financial solution to the water crisis.
\end{abstract}

Keywords: water law, water tax, water protection, environmental law

\section{Introduction}

Water is our natural treasure that has played a decisive role through the history and in the future, it will also play an important role considering economic and social development. Adam Smith's findings on water parathion points out its special nature. Water as a primary element of life is of little value, while less valuable natural treasures such as diamonds represent significant monetary value. Economics certainly gives the exact answer to the question, but the paradox focuses on the value of water. ${ }^{1}$ Climate change and pollution, however, are beginning to overwhelm this paradox in several areas of the world where people no longer have access to clean water. The economic and social prognoses are facing serious problems. The water crisis encourages governments to seek for solution to the problem and to find new complex regulatory options which preserve and renew this significant natural resource. ${ }^{2}$

Zoltán Nagy: The question of water and management of water resources from the point of view of domestic environmental financial regulations - A víz és vízgazdálkodás kérdései a hazai környezeti pénzügyi szabályozás szempontjából. Journal of Agricultural and Environmental Law ISSN 1788-6171, 2019 Vol. XIV No. 26 pp. 162-192 doi: 10.21029/JAEL.2019.26.162

* dr. jur., PhD, Dr. habil, full professor, University of Miskolc, Faculty of Law, Institute of Public Law, Department of Finance Law, e-mail: jogdrnz@uni-miskolc.hu .

** This study has been written as part of the Ministry of Justice programme aiming to raise the standard of law education.

${ }^{1}$ Samuelson \& Nordhaus 2012, 86-88.

${ }^{2}$ Szilágyi 2018, 23-26; Lentner 2018; Lentner 2017, 13-26. 
Within water-based governance, the base area is water management, which includes both political and financial issues. ${ }^{3}$ Considering the subject, the latter has more significance. Determining the value of ecosystem services is an important step and can be used to influence its consumption and protection. From my point of view, in water management, economic regulation, which can be implemented through the means of financial regulation, is more important than the official banning rules. ${ }^{4}$

The influence of water protection and consumption can be achieved through the regulation of environmental taxes and the regulation of other payment obligations. We can talk about passive financial instruments of water protection that protect the water base from excessive pollution. Such a device is the soil load fee and the water discharge fee. The former is payable for the groundwater load, while the latter is payable for the surface water load. Active defense devices fortify the use of water by charging for the use of the environmental element. The active defense financial instruments include water resources contributions, user charges and a potential instrument could be water taxation.

All these financial instruments can protect existing water resources on a market basis, but the question is whether the current regulatory instruments are sufficient enough. In this article, the current regulation is examined, considering the regulatory problems.

\section{The tax law defense of encumbrance of surface and subsurface waters}

The environment encumbrance charge serves the defense of surface and subsurface waters. ${ }^{5}$ The environment encumbrance charge was regulated as particular rates and taxes. The legal literature refers to it as a technological tax payment obligation. ${ }^{6}$ The legal regulation ranks it among the ecological taxes. Consequently, the environment encumbrance charge can be considered as a particular issue tax since it bears all the characteristics of taxes therefore it would be more appropriate to call it tax instead of naming it as charge. ${ }^{7}$ Furthermore, the nature of tax is strengthened by the fact that the Act of the rules of taxation applies to it, as regards on the basis of this it is qualified as a tax. ${ }^{8}$ The encumbrance of the environment means emission of some material or energy, environmental pollution means the emission above the limit therefore these means equal the emission-based issue tax as it is known in the international legal literature. ${ }^{9}$

\footnotetext{
3 Szilágyi 2018, 30.

4 Tóth 2016.

${ }^{5}$ Nagy 2013, 180-188.

${ }^{6}$ Borsányi 2003, 5 .

7 Kerekes 1998, 98.; Koloszár 2004, 23.

${ }^{8}$ Rabné 2008, 61.

${ }^{9}$ Borsányi 2009, 23.
} 
Despite this, the environmental protection act classifies it in the category of fees to be paid after the utilization of environment as a charge which creates the funds of the measures which decrease the encumbrance and requisition of the environment. ${ }^{10}$

In the EU we can't find significant directions, regulations about the environment encumbrance charge apart from the energy tax so the member states can form their own rules freely in environmental protection action programs. ${ }^{11}$ Typically, in all the member states it was introduced in the same form typically water encumbrance charge or air encumbrance charge. Mainly in the member states newly joined in 2004, the soil encumbrance charge was introduced. ${ }^{12}$

The possibility of introducing the charge was created by the environmental protection act which defines the substance of the charge. The user of the environment is obliged to pay charge for the environment encumbrance which can be defined for such a material or type of energy which has a measurement standard, as regards the emission of which can be ascertained reliably by scales or on the basis of technical calculation. ${ }^{13}$

The objective of the regulation is to place the reasonable usage of our environment on new grounds. The justification of the act shows that the possibilities provided by the natural environment are not infinite since the increased use leads to the consuming of the environmental values. However, the costs of the exaggerated encumbrance and contamination are not presented at the causer, but all the society bears the burden therefore it is important to establish a system regulation which makes the user of the environment be concerned about the decreasing of the encumbrance of the environment. ${ }^{14}$ On the other hand, it is necessary to involve the users of the environment in the financing of the taken measures in the protection and reinstatement of the environment. The environment encumbrance charge defines the price of the emission of the materials which encumber the environment influencing the economic decisions of the household consumers and the smallholders. The particularity of the charge is that it is not just to be paid in the case of exceeding the emission limit but for all the units of materials or energy emitted into the environment. It is necessary because the environmental damage can be realized in the case of the under-limit emission. The environment encumbrance charge is not a sanction, but it is the means of the economical appearance of the responsibility for the environment. The charge effects on the smallholders' profitability and competitiveness as economical means and payment obligation, therefore various principles were drafted during establishing the regulations. ${ }^{15}$ Through the gradual introduction, the emitters are not encumbered to the obligation to pay the full charge, it has had to be paid since 2008. Furthermore, such a principle is the legal institution of claiming back the charge which serves double objectives, on one hand it helps the appearance of the effective environment protection

\footnotetext{
10 Act LIII of 1995 (Ktv), \59 (1).

${ }^{11}$ Erdős \& Rónai 2014; Erdős 2012.

12 Borsányi 2009, 6.

13 Ktv. $\int 60$.

${ }^{14}$ Nagy 2011, 252-255.

${ }^{15}$ Borsányi 2003, 23.
} 
technics, on the other hand it extenuates the rates and taxes of the lower level activity of the environmental pollution. The regulation distinguishes among the charges in accordance to the environment polluting materials in terms of environment protection, it prefers the applying of environment conscious materials. ${ }^{16}$

The environment encumbrance charge can be levied on materials and types of energy on the basis of the he environmental protection act, that is the object of the tax can be energy beside materials. But the act of environment encumbrance charge considers only the environment encumbrance materials as objects of the tax, it determines encumbrance charge only on these, the products of energy belong to the effect of the excise tax act. ${ }^{17}$

The act of environment encumbrance charge defines three kinds of environmental pollution, i.e. the obligation of paying charge is established in the case of the environment encumbering materials brought by the emitter into the air, into the surface waters and into the soil. Depending on the contamination three kinds of environment encumbrance charge can be distinguished, the charge of air encumbrance, the charge of soil encumbrance and the charge of water encumbrance.

In the system of the act general and special regulations were determined. In the framework of the general, common regulation taxpaying, tax liability, charge allowances, rules of procedure were drafted. The special provisions settle the regulations referring to the particular charges.

The taxpayer of the environment encumbrance charge is the emitter. The concept of the emitter belongs to the environment users who emit materials into the environment during the use of the environment which requires permission. The concept of the environment user is defined by the environmental protection act. ${ }^{18}$ The act decrees the tax liability for the emitter and the environment encumbrance materials. ${ }^{19}$

That emitter is obliged to pay the charge of air encumbrance who has an air polluting point source tied to place which requires notification. The tax liability encumbers only determined air-encumbering materials such as Sulphur dioxide, nitrogen-oxides and other non-toxic solid materials. The degree of the charge is defined by the grounds of the charge of air encumbrance (the mass of the yearly quantity of the air-encumbering material) and the unit charge of the air-encumbering material. The specialty of the regulation is that it concentrates only on few air polluting materials of state of gas which is justified that the degree of anthropogenic emission of these materials exceed by far the degree of natural emission. However, in the case of few polluters which are not under the scope of the regulation, the degree of natural emission is much bigger (carbon dioxide, Sulphur hydrogen, ammonia). ${ }^{20}$

\footnotetext{
16 Borsányi 2003, 23.

17 Act LXXXIX of 2003 (Ktd).

${ }^{18} \mathrm{Ktv}, \int 2(2)$.

${ }^{19} \mathrm{Ktd}, \$ 2 \mathrm{~b} /$.

20 Szablyár 2005, 33.
} 
The necessity of the introduction of water encumbrance charges is justified that our waters are more and more polluted by the water-encumbering materials. ${ }^{21}$ The encumbrance of our waters is regulated by the law with two kinds of charges. In the case of the encumbrance of surface waters the obligation exists to pay water encumbrance charge, in the case of the encumbrance of subsoil waters the obligation exists to pay soil encumbrance charge, the regulation names the water-encumbering materials thus the charge has to be paid in the case if these materials get into the surface water. ${ }^{22}$ The obligation to pay water encumbrance charges encumbers that emitter who carries out activities under the authorization of water laws.

The degree of the charge is regulated by a system which pays attention to various factors. The water supplier is obliged to put at the emitter's disposal the quantity of the water-encumbering materials which are justified by authentic measurements. (If the water supplier does not fulfil this obligation the competent environmental protection authority carries out the measurements and ascertains the payment obligation and burdens it on the water supplier, its cost is five times more than the normal charge of the measurement.) The degree of the charge is determined by the unit charge of the water-encumbering materials and the multipliers of the territorial sensitivity and mud-placing. The multiplier of the territorial sensitivity pays attention to territories from the point of view of protection while the multiplier of mud-placing distinguishes by the way of placing and pays attention to the territorial categories. ${ }^{23}$ The way of placing can be agricultural utilization -, with the lowest multiplier-, burning, other temporal storing and placing it in unloading area.

The law determines tax exemptions and premium discounts. These belong to the tax exemptions: (a) the reutilization of water if it doesn't encumber surface water; (b) the quantity of water-encumbering materials being originally in the water; (c) the quantity of the conducted rainfall water; (d) heavy metals if the emission of such materials is excluded; (e) fish pond operated in an extensive way.

The charge is paid by the water and sewage works that conduct the sewage into public drains and later they let it go to surface waters and by the companies of industry that produce liquid waste. ${ }^{24}$ However, the charge can be reversed to the users of the service.

The opportunity of charge allowance is established by the law. The emitter can have $50 \%$ of charge allowance if they implement an investment project which decreases the water encumbrance of surface waters during the implementation time of the investment project for 5 years at the longest. The condition of the charge allowance is the definitive water law establishment permission of the investment project. ${ }^{25}$ The law prescribes as a sanction in the case of the charge of air encumbrance and water encumbrance if the investment project is not placed into service until the time

\footnotetext{
${ }^{21}$ Schwartmann 2006, 106-107.; Olajos 2006. 106-111.

$22 \mathrm{Ktd}$, Annex 2.

${ }^{23} \mathrm{Ktd}$, Annex 2.

${ }^{24}$ Borsányi 2003, 23.; Csák \& Raisz 2008.

${ }^{25} \mathrm{Ktd}$, $\ 15$ (2), Governmental Decree No 270/2003.
} 
determined in the implementation permission, for 5 years at the longest, the sum of the charge allowance is due back, increased with the double of the central bank base rate.

Soil and groundwater contaminations were previously given less attention. For many years, the by-products of air and wastewater treatment have been deposited in land-based landfills, causing significant environmental damage. Further damage was caused by chemical fertilizers, insecticides and by the waste disposal sites operated without the necessary protection. ${ }^{26}$ It is necessary to apply the environment encumbrance charge to prevent the further subsoil contamination and, in the interest, to promote the self-purification processes. ${ }^{27}$ The legal literature determines important criteria so that the regulation could succeed in its object: ${ }^{28}$ (a) it should comprehend the more widespread scope of polluters as possible; (b) it should apply to the most widespread scope of polluting materials; (c) the magnitude of the charge should reflect the magnitude, danger and receptive sensitivity of the encumbrance; (d) its implementation and determination should be simple; (e) the revenue of the charge should serve environmental objectives and investment projects.

The domestic regulation conforms to these criteria. ${ }^{29}$

The obligation to pay soil encumbrance charge is compulsory in the case of subsoil waters. While the air encumbrance and the water encumbrance belong to the jurisdiction of the State Tax Authority, the competent local government tax authority proceeds the soil encumbrance tied to the sewage conduction and the charge constitutes the income of the environment protection fund of the local government. The income from the soil encumbrance charge is targeted because it can be used only for the quality and quantity protection of the soil and the subsoil water. Canalization, wastewater purification, protection of water base, remediation, technical protection before and after the contamination are qualified as such uses.

The obligation to pay soil encumbrance charge is encumbered on the emitter who carries out sewage conducting on the basis of authorization of local water management authority and water law and who doesn't attach to the technically available sewage network. ${ }^{30}$

The basis of the charge is the quantity of the water which is served or justified by special measuring or rather determined in lump sum. The degree of the charge is determined by unit charge together with territory sensitive multiplier referring to the territory of the local government. ${ }^{31}$ The law does not establish charge allowance, but it establishes exemption. The legislator regulates exemption in two cases if the emitter uses sewage placing small establishment, special sewage purifying equipment or the utilization of watering is exempt. ${ }^{32}$

\footnotetext{
${ }^{26}$ Szablyár 2005, 33-34.; Raisz 2012.

27 Tózsa 2000, 31.

${ }^{28}$ Megyeri, Katona \& Ferencz 1996, 37.

${ }^{29} \mathrm{Ktd}, \mathbb{\Omega} 21 / \mathrm{B}$.

${ }^{30} \mathrm{Ktd}, \int 11$ (1).

${ }^{31} \mathrm{Ktd}$, Annex 2.

${ }^{32} \mathrm{Ktd}, \mathbb{S} 11$ (2).
} 


\section{The protection of the utilization of water with help of rates and taxes}

In addition to the water encumbrance, important interest of the society relates to the financial and environmental legal utilization of water. The requisitioned contribution serves this purpose. The concept of requisitioned contribution is recorded by the environment protection regulation. ${ }^{33}$ The requisitioned contribution is such an obligation of payment which is imposed for the requisition of environmental element i.e. it is imposed for the utilization of some environmental element as a natural resource. ${ }^{34}$

We differentiate the resources according to that, they are renewable or nonrenewable ones. The legal literature ranks among the non-renewable resources those resources which reproduce themselves, but on such a long term that it is irrelevant economically, respectively the exploitation is so intensive that the sustainability of the reproduction is not assured. ${ }^{35}$ Thus, the value of the resource is given by the fact that it collaborates in the manufacturing of other products, however the resource will not be available in the future by means of being consumed. The owner of the resource gets extra income assuring the opportunity to exploit and use up the resources. It can appear in the form of royalty or rent. In Hungary the treasures of the earth due the state (fossil energy sources, too.) The state collects annuity from the users which forms the revenue of the central budget or rather it means extra costs for the exploiter, user of the resource. The legal literature typically emphasizes two requisitioned contributions from the system of payment obligations, the acreage rent and water resource contribution. ${ }^{36}$

Waste water charges and taxes are widespread in the European Union and the bases of the similar method are regulated in the individual countries. ${ }^{37}$

This kind of requisitioned contribution, the water resource contribution was introduced in order to provide the defense of resources of surface and subsurface waters and the necessary sources of the defense. ${ }^{38}$

The tax law status of water resource contribution is special because the legal regulations of the water management depose of the questions of the procedure as a main rule and the Tax Authority should be understood as the Water Authority. The tax law status of the water resource contribution is special because the legal regulations of water management depose of the questions of the procedure as a main rule. The act on the rule of taxation has to be implemented on the procedure questions as a vicarious rule with that, certain regulations (the reduction of contribution, the reduction of legal consequences) can't be implemented by the Water Authority. It can be established that the water resource contribution is a special payment obligation which has neighboring regulations with the taxes it disposes special regulations which are different from those.

\footnotetext{
${ }^{33} \mathrm{Ktv}$, 61. $\$$.

${ }^{34}$ Csák 2008, 38.

35 Nagy 2012.

${ }^{36}$ Fucskó et al. 2000. 41-45.

${ }^{37}$ Laskowska \& Scrimgeur 2002, 1-12.

${ }^{38}$ Szakács 2010, 1437.
} 
The defense of the water is detailed regulated theme in the international, European and domestic law. ${ }^{39}$ The water as part of our national heritage has constitutional protection respectively the legislator protects the quality, the quantity of the water resource and provides the conditions of the rational water management. ${ }^{40}$ It is necessary to pay contribution, consent or charge of interest in order to reimburse the expenditure of the society partially or fully, the enforcement of this principle creates the legal political grounds to levy water resource contribution. ${ }^{41}$

The detail regulations of the water resource contribution is determined by the law of water management and ministerial decree. ${ }^{42}$ The object of the contribution is actually the used quantity of water which was booked in establishment and maintenance permission of water law or was used up without permission. The subject of the contribution is the user of water or the industrial consumer. ${ }^{43}$ The subjects are encumbered by contributional obligation which involves the obligation of announcement, the obligation of paying contribution and the obligation of filing a statement.

In the frame of the announcement of the obligation the obligor is compelled to pay the water resource contribution from the date (receipt of the water law permission depending on the taxpayer's beginning of utilization of water) in the calculated 15 days and compelled to announce it to the competent Water Authority. The obligation to pay contribution is subject to special regulation since it is originated at the user of water with the receipt of the final permission of water law, at the industrial consumer with the beginning of utilization of water. In the frame of filing a statement, the taxpayer is compelled to give a declaration to the competent Water Authority about the de facto requisition of water, the basic data of the payment obligation, its calculating, the legal grounds of the paid amounts.

The basis of the water resource contribution is the quantity of water utilization which was de facto requisitioned and defined in cubic meters, however special regulations are enforced in the case of water utilization without permission to determine the quantity of water. ${ }^{44}$ The law determines basic contribution at establishing its degree in accordance to the obliged, respectively, it determines the degree of the water resource contribution with the help of a multiplying number which takes into consideration different factors. The basic contribution is different according to user of water, user of water without permission and industrial consumer. ${ }^{45}$ This basic contribution is one of the factors which serves to calculate the product of the degree. This basis contribution is one of the factors of the product to calculate the degree.

${ }^{39}$ Miklós ed. 2011, 75.; EEC Directive 98/83, EEC Directive 76/464, EEC Directive 91/271, EC Directive 2000/60 (Water Framework Directive).

${ }^{40}$ Miklós ed. 2011, 75.; Act LVII of 1995 (Vgt) \$S 15/A-15/E.

${ }^{41}$ Bándi 2011, 454.

42 KHVM decree No 43/1999.

$43 \mathrm{Vgt}, \int 15 / \mathrm{A}(2)$.

${ }^{44}$ KHVM decree No 43/1999.

$45 \mathrm{Vgt}, \int 15 / \mathrm{B}$. 
The calculation of the water resource contribution with the product takes into consideration the nature of the water resource beside the basis contribution (surface, subsurface waters, respectively the nature of the utilization of water (medical purpose, public purpose, economical purpose) on the basis of these it determines the multiplying number (from 0.5 to 10) which changes the degree of the water resource contribution in comparison with the basis contribution. ${ }^{46}$ Furthermore, the formula is complicated that the surface waters are categorized as watercourse with regard to utilization, quality and national economy input.

Two categories of exemption of water resource contribution can be differentiated the exemption of user of the water and the exemption of the industrial consumer i.e. the exemption is differentiated by the legislator as taxpayers. ${ }^{47}$ Two categories of user of the water can be differentiated in the scope of automatic exemptions, respectively the exemptions ensured on petitions. In the case of automatic exemptions the law lists those cases itemized when the user of the water does not have to pay water resource contribution. 48 In the case of the exemptions ensured on petitions the user of water is not encumbered by payment obligation for supplying firewater, for the quantity of water serving civil protection preparedness purposes, furthermore for the exploited quantity of water in the case of water in crush in mine causing life danger and for that part of quantity of water according to water law permission which cannot be requisitioned because the water resource is not at disposal from natural reasons. ${ }^{49}$

The industrial consumer does not have to pay water resource contribution in the case of exemption of the industrial consuming if the public health requirements determine the quality of drinking water for the quantity of more than $50 \%$ of the requisitioned water.

In connection with ensuring exemption problems arose in the judicial practice, too. ${ }^{50}$ In the case of the object of the lawsuit, the industrial water supply necessary to the wet classification was provided from the water of the mine lake in the gravel-pit but the water coming from the classifying equipment was conducted back to the gravel-pit mine lake through a water canal. The Water Authority obliged the user of the water to pay water resource contribution. The user of the water referred to the fact, that legal exemption applies to their activity. The exploitation of quantity of water which is identical with the quantity of water fed into groundwater enrichment exempt from water resource contribution if it comes from aquifer layer requisitioned with soil enrichment. The Supreme Court (Curia) dismissed the exemption and explicated why the activity of the user of the water cannot be ranked in the scope of the exemption. According to the view of the Supreme Court (Curia) the user of the water does not accomplish soil enrichment with that they conduct back the used water into the mine lake in identical quantity.

\footnotetext{
46 KHVM decree No 43/1999, Annexes 1-2.

47 Szakács 2012, 1438.

$48 \mathrm{Vgt}, \int 15 / \mathrm{C}$.

${ }^{49}$ Szakács 2012, 1438.

${ }^{50}$ Judgement of Hungarian Curia No Kfv. III. 37.104/2008/3.
} 
The activity suitable to the exemption case means definitely the intake with the purpose of increasing the quantity of groundwaters, the final purpose of which is the improving the quality of the water to exploit. In fact, according to the view of the Court the reinjection can exclusively be construed in the case of water layer-well under pressure. On the basis of all these the Court established the obligation to pay contribution.

\section{The protection of water with utilization charges}

The urban public service system defines a wide range of public service tasks, which raises different policy issues. ${ }^{51}$ Water supply also falls within the scope of public service tasks, so it has to bear with the problems of other public service tasks. Public service provision is not provided directly by local governments, but they are provided through service providers, or as a subscriber to public service providers. However, there are several problems with service provision.

On the one hand, it is considered to be a mandatory task provision, this means that the task must be provided regardless of the price and the fee of the service. The municipality must use the service regardless of its price.

An important problem in the area of public services is the position of relative service monopoly. There are few service providers in the given sector, so market conditions do not necessarily prevail in this area.

Market conditions are further distorted by consumer price sensitivity, from which a political issue also arises. The price sensitivity of the Hungarian population is extremely high, which is due to the fact that public utility charges account for a substantial part of household income, almost a quarter. The low level of income and the capacity of retail service providers cannot be increased significantly either. Due to price sensitivity, the level of overhead costs has also become a major issue for policy, as pricing is not only influenced by market and economic issues.

In the context of the services, there are also efficiency problems that influence pricing. Relatively high fixed costs are charged to consumers. In many cases, this is so high, that an unbiased price could be created, so it cannot be passed on in the price. This represents a significant subsidy demand from local governments to service providers. ${ }^{52}$

Serious problems are also caused by the outdated technological background, the lack of development, which generates significant network losses. These losses, however, appear in the price and also make the services more expensive. The characteristics of urban management services are that fees are determined by the new regulation, taking into account the justified costs and subjecting the utilities a determination of charges.

In addition, charges are also determined by the reduction of the overhead, which limits the increase in fees by determining a maximum price and reduces the charges compared to the previous years.

\footnotetext{
${ }^{51}$ Nagy 2016, 287-292.

52 Szilágyi \& Tóth 2018, 49-56.
} 
Among the supertax, municipalities and utilities are significantly affected by the tax on public utilities, ${ }^{53}$ which, in addition to the heat and electricity supply, also carries water, sewage, rainwater drainage pipelines along with the communication lines. The tax therefore does not cover all urban service. The tax has a direct effect on municipal management, since the operator of the utility is the taxpayer and typically the local government-owned enterprises operate the water supply and heat supply pipelines, so they are also affected by the tax. Because of the fixed tariffs, the tax also affects the local government's management, as the local government needs to ensure the operation of the service providers. Among the several supertaxes, this property-based tax has one of the greatest effects on municipal management.

The comparison and analysis of water related charges and fees in the European Union has been difficult because of the fact that most of the charges are levied at urban and regional level. In terms of form, water tariffs have been regulated differently in different countries, due to the fact that water use measurement is not a used method in every country, a flat rate or specific tariffs will be established based on different tax base methods. The tax base can be the value of the property (England) or the location of the house (Norway). Special tariffs (so-called block tariffs) are set in some large cities (Zürich, Barcelona), as the cost of water and sewage services is part of local taxes. There is also a difference in the VAT on water supply and sewer, as in some countries (Denmark, Finland) the normal tax rate is used, while elsewhere these services are subject to reduced turnover tax (Belgium, France, Germany). In order to subservience water saving, the Netherlands introduced a tax on the use of groundwater in 1995, depending on the consumer, and in 2000, a new tax was introduced on water use, water transport. In 1994, Denmark introduced water taxation, but it is only paid by households.

In the case of water utility tariffs, ${ }^{54}$ specific principles apply to the pricing of the fee, and the fee system is also affected by the overhead reduction system. ${ }^{55}$

The fee structure is determined, but the law allows that fees differ from one to another service provider or sector. However, several principles and criteria are prevailing in the pricing.

The wide point system has laid the foundations of a justified and necessary level of fees, so the overhead reductions are not necessarily reasons in the formation of principles and fees. If the legislator finds that the remuneration does not comply with the statutory principles, to change the remuneration they provide effective means of legal regulation in the form of fee administration. The Hungarian Energy and Utilities Regulatory Authority ${ }^{56}$ is responsible for the supervision of fees under which it is entitled to act in case of breach of the principles of remuneration. It may prohibit the infringement fee for further application, reimburse the generated additional revenue to the consumers with a default interest, or impose fines. It is therefore clear that a legal framework for compliance with regulated, principles-based tariffs was covered without

\footnotetext{
53 Act CLXVIII of 2012

54 Act CCIX of 2011.

55 Act LIV of 2013.

56 Act XXII of 2013.
} 
the overhead reduction. If, however, the $10 \%$ overhead reduction in the appropriate level of charge is imposed, it causes a difficult economic situation for the service providers, and governments need to provide extra resources for the service. In addition, public utility drinking water supply and sanitation, cleaning fees are official fees, which are defined in a ministerial decree. A fee other than the official fee in a public utility contract may be offset by the prior consent of the Agency. The system is further complicated by the fact that there are costs that charge the cost of a water utility service or the law make a difference between consumers. The fee for the water utility service consists of a basic charge and a fee proportional to consumption. At a fee that is proportional to consumption, a lower fee system for retail users can be determined against non-residential consumers.

In addition to the fee, the service fee of connecting to the water utility and the contribution of water utility development can be established. The former represents the transfer price of drinking water between providers and the sewage treatment fee. The development contribution is paid by non-residential users, which will buy a public utility quota, so they will be entitled to use the service up to the quota.

Public service for the collection of household sewage is also used to avoid pollution, which is an obligation that is compulsory for the local government. ${ }^{57}$

The local government defines its own pricing policy and determines the payment obligation in the local government decree, the maximum rate of application, the order of payment and the scope of the discounts and exemptions. (It is important to note that the fee is considered to be a public due, to be levied as taxes.)

The law stipulates the obligations that are proportional to the amount of sewage and the pricing which takes into account the investment requirement. According to the intention of the legislator, the fee includes the costs of operating expenses, maintenance expenses and emerged investment expenses.

From the point of remuneration, two types of fees can be identified, the singlefactor and the two-factor fee. A two-factor fee is mandatory for the municipalities involved in the National Settlement and Sewerage and Purification Program. ${ }^{58}$ The municipality accepts the fee calculation on the basis of the abovementioned statutory guidelines. This is overwritten by the overhead reduction, which reduces the fees by $10 \%$, in a pivotal legal form in 2013. The consumer protection authority is appointed for monitoring the overhead reduction. The question is that what the intention of the legislator in the present case was, since the 2012's modification of the proportional and necessary fee system took place on January 1, 2013. In my view, it would have been sufficient therefore to check compliance with the rate of charge, because if the municipalities comply with the spirit of the law, realistic fees would be evolving. The legislator therefore either did not trust the effectiveness of the law on the issue of remuneration or did not take into account the statutory conditions and decided to apply the reduction of overhead under the across-the-board principle. ${ }^{9}$

\footnotetext{
$57 \mathrm{Vgt}, \iiint_{44 / B-44 / J}$

${ }^{58} \mathrm{Vgt}, \int 44 / \mathrm{D}$.

${ }^{59}$ Act CXIV of 2013.
} 


\section{Summary, and a possible solution the water tax}

The study pointed out the problems of water-related financial regulation. The regulation has to consider water-related economic and social issues. Water is not only a primary condition for human life, but also an essential resource for economic activity. It is necessary to ensure that household consumers have access to fair prices and economic operators at prices and terms that does not interfere their activity and ensure their competitiveness. On the other hand, there is limited natural resources available, whose reproduction must be guaranteed, and use must be sustained. The presented financial instruments show that it is a complicated, highly politicized system that is difficult to change, though it should. There is a need for change in a more cost-effective utilization and for building a more up-to-date line and service system. Funds could be provided by the introduction of water tax. Income tax would be the revenue of a local government that could be only used for protecting the water base and improving the service. The transmitter could be a lane progressive tax in which the lanes would be formed in the proportion of consumption and a 0 percent or a minimum amount would be established for a lower consumption rate. The tax would aid the protection of natural resources and stimulate a more efficient consumption.

Generally, taxes are not popular tools, however in my opinion, it is a less bad than limiting water consumption in the long run with official means or writing to the service provider that 'water has run out'. 


\section{Bibliography}

1. Bándi Gy (2011) Környezęjog, Szent István Társulat, Budapest.

2. Borsányi B L (2003) Környezetterhelési díjak, Környez̨etvédelem 11(6), p. 23.

3. Csák Cs \& Raisz A (2008) Trinkwasserskandal in der drittgrösten Stadt Ungarns: Theorie und Praxis der Haftung im hungarischen Umweltrecht, in: Caelies C, Härtel I \& Veit B, ed., Jahrbuch des Agrarrechts, Nomos, Baden-Baden, pp. 165-176.

4. Csák Cs (2008) Környezetjog I., Novotni Kiadó, Miskolc.

5. Erdős É \& Rónai O (2014) Energy Taxation: a point of view of the unsettled legal background of a biomass-heating plant, Materials Science and Engineering 39(2), pp. 115-129.

6. Erdős É (2012) Adalékok egy biomassza fütőmű rendezetlen jogi hátteréhez, in: Csák Cs, ed., Jogtudományi Tanulmányok a fenntartható természeti eróforrások témakörében, Miskolci Egyetem, Miskolc, pp. 40-53.

7. Fucskó J, Kis A, Bela Gy, Krajner P \& Valené K Á (2000) Ökológia adóreform II., Magyar Környezetgazdaságtani Központ, Budapest.

8. Kerekes S (1998) A környežtgazdaságtan alapjai, http:/ /mek.oszk.hu/01400/01452/html/ [06.06.2012]

9. Koloszár M (2004) Környezetterhelési díj, Adó 18(8), pp. 23-24.

10. Laskowska A \& Scrimgeur F (2002) Environmental taxation: The European experience, wms-soros.mngt.wakiato.ac.nz/NR/EuropeET.doc [06.05.2012]

11. Lentner Cs (2017) Közpénzügyi Menedzsment, Dialóg Campus, Budapest.

12. Lentner Cs (2018) Az adórendszer és a közpénzügyek egyes elméleti, jogszabályi és gyakorlati összefüggései. Európai Jog: Az Európai Jogakadémia folyóirata 18(5), pp. 30-36.

13. Megyeri M, Katona J \& Ferencz L (1996) A szennyvízterhelési díj módszerének elve a francia joggyakorlatban, Környezet és fejlódés 6(3-4), pp. 36-41.

14. Miklós L ed. (2011) A körmyezetjog alapjai, SZTE ÁJK-JATE Press, Szeged.

15. Nagy Z (2011) Fenntartható költségvetési elvonások rendszere a környezetvédelem területén, Publicationes Universitatis Miskolciensis Sectio Juridica et Politica 29(1), pp. 247-258.

16. Nagy Z (2012) A természeti erőforrás-gazdálkodás adójogi aspektusai, in: Bikkfalvi P, ed., The Publications of the XXVI. microCad International Scientific Conference, Miskolci Egyetem, Miskolc, pp. 1-5.

17. Nagy Z (2013) Környezeti adózás szabályozása a környezetpolitika rendszerében, Miskolci Egyetem, Miskolc.

18. Nagy Z (2016) Különadóztatás és díjmegállapítás, in: Horváth M. T \& Bartha I, ed., Közszolgáltatások megszervezése és politikáa- Merre tartanak?, Dialóg Campus Kiadó, Pécs-Budapest, pp. 287-292.

19. Olajos I (2006) Vízvédelem, in: Olajos I, ed., Agrárjog gyakorlat II., Novotni Kiadó, Miskolc, pp. 106-111.

20. Rabné B G (2008) Környezetterhelési díj, Adó 22(15-16), pp. 61-68.

21. Raisz A (2012) A felszín alatti vizek határon átnyúló szennyezésére vonatkozó nemzetközi szabályozás, Publicationes Universitatis Miskolcinensis Sectio Juridica et Politica 30(2), pp. 371-382. 
22. Samuelson P A \& Nordhaus W D (2012) Közgazdaságtan, Akadémiai Kiadó, Budapest.

23. Schwartmann R (2006) Umweltrecht, C.F. Müller Verlag, Heidelberg.

24. Szablyár P (2005) Ökoadó - avagy a környezetterhelési díj, Bányászati és Kobászati lapok 138(5), pp. 32-34.

25. Szakács I (2010) Az adózás nagy kézikönyve, Complex Kft., Budapest.

26. Szilágyi J \& Tóth H (2018) Kollektiv munkaügyi viták és az alternativ vitarendezés lehetöségei a villamoseneriga-ipar és a vízmüvek területén, HVG ORAC Lap-és Könyvkiadó Kft., Budapest.

27. Szilágyi J E (2018) Viæ̌szemléletü kormányzás - vízpolitika - viżjog, Miskolci Egyetemi Kiadó, Miskolc.

28. Tóth Zs (2016) Paradigmaváltás a környezeti problémák kezelésében: Az ökoszisztéma-szolgáltatás koncepció és jogi vetületei, ProFuturo (1), pp. 98-106.

29. Tózsa I (2000) A talajvízterhelés mérséklésének önkormányzati eszközrendszere, Comitatus Önkormányzati Szemle 10(6), pp. 31-39. 